\title{
WOMEN'S PLACE IN FINNISH PROVERBS FROM CHILDHOOD
}

\author{
Liisa Granbom-Herranen
}

\begin{abstract}
The purpose of this article is to introduce some features of the relationship between proverbs and gender in Finnish folklore tradition. I focus on pedagogical speech using proverbs in the life-stories from the end of the 19th century and the beginning of the 20th century. The main interest is on bringing up children concentrating on the written memories and the everyday life of ordinary people. This deals with the private level of education in childhood memories.
\end{abstract}

Kodin ilmapiiri oli lämmin ja tunsimme koko perhe olevamme yhä. Tuimme aina lasten kesken toinen toisiamme ja pienempää piti aina ohjata ja auttaa ja puolustaa. Äitini aina sanoikin että heikompaa on aina autettava ja että köyhän ainoa pääoma on rehellisyys, rehtiys ja oikeamielisyys, ja kun kasvatte suuriksi niin pitäkää itsenne miehinä, joihin voi luottaa. Eikä minunkaan ole sitten koskaan tarvinnut noista periaatteista luopua.

'The atmosphere at home was gentle and all the family felt to be one and same. We children gave our support to each other and we were supposed to guide and help and defend the smaller ones. My mother always said that you have to always help those who are weak and the only capital a poor person has is sincerity, honesty, and uprightness. When you'll be grown-ups, see that you still are those ones to whom others can trust. I have never given up those principles.'

Key words: childhood, everyday life, proverb, woman

\section{INTRODUCTION}

In this article, I focus on the gender-connected part of proverbial memories. Gender has been seen as a subject of Finnish proverbial speech mainly in two cases. First of all, the proverbs have widely been seen as a part of patriarchal and masculine speech. Secondly, women have been seen as the object of negative proverbial speech. Women are mostly connected with Finnish proverbs when the main point has been to examine the underestimation of women and womanhood. This interpretation has been the substratum for researchers of the 20 th century and even in the 21 st century. ${ }^{2}$ However, I wonder if it really is like this because the life-stories of childhood give a different perspective for 
proverbial speech. In this article I try to make the women in Finnish proverbs visible, giving some thoughts about those proverbs which are the ones we remember even in adulthood.

I look at the proverbs and the interpretations thereof in the context where the proverbs have been used. The starting point is in the narrators' own experiences and their interpretations of proverbs. In this article I address myself to one of the findings in the material, the one which is connected with gender. I concentrate on what the life-stories and the childhood memories can tell us about the relation between gender and proverbs. Are the proverbs merely a cultural tradition or do they represent a gender related part of sociocultural living?

The pedagogical discourse is a part of everyday life and proverbs are a part of that - even if the proverbs are mainly the tradition of adults. When using a proverb the speaker is supposed to use "the wise words". This is one of the reasons why proverbs have been seen to fit quite well in raising children and regarded as a powerful method of bringing up and teaching children. (GranbomHerranen 2009b: 79). Two collections from the Folklore Archives of the Finnish Literature Society in Helsinki are used as research material.

\section{STARTING POINT IN FINNISH HISTORY}

After being a part of the kingdom of Sweden for many centuries, Finland was an autonomous grand duchy of Russia from 1809 to 1917. Some parts of Finland became areas of Russia even before. As an autonomous grand duchy Finland held a special position as to the rules and regulations of state, the Lutheran church, popular education, the question of language etc. The 19th century in Finland was a time of stability; boundaries between social classes were hardly ever crossed. Both education and everyday life of the upper classes have left written material in public and private archives.

The language of proverbs used by ordinary people was Finnish. The languages of the power elite were Swedish and Russian (German, French). However, these upper classes were a minority and the language they used differed from the language of the underprivileged Finnish speaking majority. The Finnish proverbs were a form of speech used by a group that was the minority from the point of view of social power (Katajala 2005: 43-51; Granbom-Herranen 2008: 116-117). Language is a tool of cultural expression, which also controls all of life through its concepts (Devitt \& Sterelny 1987: 116, 172) so from the social point of view even the use of the Finnish language has formed a separating barrier between ordinary people and the upper social classes. ${ }^{3}$ Passing 
from one generation to another, proverbs have been the speech of the family and neighbourhood.

My ambition is to get in touch with the time when oral information was in a central position. For the majority the end of the 19th century, and the beginning of the 20th century, was the time of unwritten information and knowledge, as illiteracy remained to be common in Finland as late as until the beginning of the 20th century. Even if there were some Finnish speakers who could read and write in the 19th century (Stark 2008), it was still the time when the majority of Finnish children spent their childhood without schooling. The power of proverbs and pedagogical speech becomes more obvious in societies which are not based on written knowledge. The ability to read and thereby the possibility to select information is not self-evident for people living in a society with unwritten memory (Pentikäinen 1980: 206; Finnegan 1994: 32). ${ }^{4}$ The exercise of power and authority is also based on oral norms and standards, which are transmitted through upbringing from one generation to another. In the oral tradition, the instructions must be clear and easy to remember. In the agrarian context, the oral tradition has been (and still often is) more important than written knowledge (Siikala 1984: 182).

The parents and grandparents (who brought up children) at the beginning of the 20th century, had been children in the 19th century and that is when they adopted the proverbs as a part of their own speech. The slowness of the changes both in society and everyday life strengthen the effect of traditional upbringing and the oral information used in it (Granbom-Herranen 2008: 3840). Speaking and setting an example were the most important methods of raising children. In the era I focus on, the majority of children lived in rural areas and their upbringing and training normally took place at home or under comparable circumstances in households. Agriculture was the main source of living, so in everyday life children usually participated in work with grown-ups or older children (Granbom-Herranen 2008: 273).

\section{PROVERBIAL EXPRESSIONS IN LIFE-STORIES}

Looking at everyday life I use the concepts life-story and narration when talking about narrative biographies and autobiographies. A life-story is a story without an end and can be told at any point of one's life. It is not a narration of a complete life and it has not to be the whole story (Titon 1980: 276-277; Dolby 1989). A narration can be written or oral: it conveys your story to somebody, a real or an imaginary listener. Narrating one's life-story is to share memories with somebody; it allows the listener to participate in one's memories. I deal 
with written memories, storytelling in written form. The narrators do not tell the truth about the past, but neither do they lie. They tell about the past as they remember it and as they think it was (Granbom-Herranen 2008: 52-59; 2009a: 154-155; Korkiakangas 1996: 26; Ukkonen 2000: 88-90).

In the essence of a proverb there is the expectance that it is a part of common knowledge, it has a form and it involves an idea (Taylor 1994: 3). I speak about the proverbs in a quite wide meaning - this being justified by the fact that the narrators use the concepts "proverb", "saying", "Bible quotations" etc. as synonyms. In defining what a proverb is, I accept the view of the narrators (Granbom-Herranen 2004: 7-11, Appendix 2). ${ }^{5}$ When talking about proverbs there exists a common ground in a couple of features: the proverb is a short expression that is somehow traditional. According to the Finnish folkloristic definition, proverbs are common among ordinary people (in Finnish kansa, in Estonian rahvas). In Finnish kansa can contain the whole population in some country or it can mean a part of the population defined by the language or social status. This question is quite fundamental in a society where social segmentation is the same as the segmentation by language - as was the situation in Finland during the 19th century and even at the beginning of 20th century. The proverbs in Finnish have been a part of the language of the underprivileged majority (Granbom-Herranen 2008: 116-120).

Through narratives, i.e. written life-stories, we can get in touch with memories and interpretations of proverbs in childhood. We can also reach something of the context as proverbs have been (and still are) a part of pedagogical speech and the culture of everyday life. What the child remembers and recounts as a listener is not the intention of the speaker. In spite of that, later in his/her life it is possible that those obvious and/or hidden meanings are the reasons why a specific proverb is used in some situations - or vice versa, there are situations which cannot occur without using a proverb.

My viewpoint is based on the idea that everyday life has been (and still is) the stage of learning and upbringing - and that is how it is also a part of education. Trying to get in touch with ordinary people's everyday life and its routines I use narrative material. These examples are from the Folklore Archives of the Finnish Literature Society in Helsinki. The collections are Perinne elämässäni ('Tradition in my life', transl. L. G.-H.), from the year 1985 and Karjalaiset elämäkerrat ('Karelian biographies', transl. L. G.-H.), 1983-1984. Narratives have been collected during the years 1983-1985 and the age range of the narrators is from 55 to 85 years. The memories of childhood include episodes which tell about the proverbs heard in childhood and recalled in adulthood. I focus on the upbringing of children at home when oral information had the main role in education and training - at least for the majority of children 
in Finland. I confine myself to the narrators born before 1930, because they lived their childhood in Finland before the end of the Second World War. The war can be seen as a turning point in many ways: people from Eastern Finland (Karelia) were evacuated and the whole Finnish society had to be reorganised; compulsory public education became comprehensive and this way the children were connected to the social system more tightly than before; urbanisation was going on and the surroundings changing; economic life and the trades were changing. Oral tradition was no longer as meaningful and powerful as it had been during the time of stability.

My method in processing life-stories is reading and sorting out narrative texts, involving the use of the so-called emphatetic reading method of narratives. I have scanned through all the materials in these two collections and picked life-stories containing proverbs, and from these life-stories I then picked the ones in which proverbs were a part of childhood memories. These proverbs are a part of a listener's narration. In the life-stories, the proverbs are rather a part of the story than something the narrator concentrated on. They are a part of both written memories and oral tradition and using these collections, I familiarised myself with the life-stories of over one thousand people. The narrative research material comprises the life-stories of 141 narrators, including all the episodes containing pedagogical speech with proverbs. There were altogether some 300 relevant episodes and over 500 proverbs (GranbomHerranen 2008: 60).

\section{PROVERBS OF WOMEN AND EVERYDAY LIFE}

Everyday life is full of opportunities to learn the manners, norms and attitudes in society. These are the things that are easily included in proverbs, and using proverbs in the learning process is not only a matter of information and knowledge, it is combined with many kinds of feelings and emotions. Anyhow, the speaker is in a powerful position making it essential to understand who is speaking, whose speech it is that matters. When a child comes across a proverb it is always in context - cultural, social and situational context (Ricoeur 1980: 156-157; Granbom-Herranen 2008: 204, 273). Proverbs are expressions of authority, one of the first in one's life. Children pick up more than words, and proverbs are connected with the situation. Proverbs are also connected with the speaker, although he/she is seen as a part of the situation as a whole. The most important thing is the activity that is going on when the proverb is heard. A child lives his/her life and experiences situations, understands and deals with concepts quite comprehensively. 
Traditions, different folkloristic genres are mostly bound to some specific groups which can be related to age, gender, locality etc. The groups have their own way to create and keep up their oral tradition or cultural customs. Proverbs are mainly the tradition of adults who use and are allowed to use them. In the pedagogical context proverbs are passed on into the lives of children; this way the proverbs become a part of folkloristic tradition shared by different age groups. However, proverbs are shared from different points of view: from that of the speaker (the adult) and the listener (the child).

The best known genre bounded knowledge within Finnish proverbs can be found among the conclusions made by Matti Kuusi, with regard to women and the women's place in proverbs. In the course of Finnish history the use of proverbs has been seen as gender related: the proverbs have been seen as parts of masculine talk. Proverbs have also been considered as cornerstones for the patriarchal society (Kuusi 1954: 91-92; 1971: 100). These assumptions fail to work when we look at the proverbs from a childhood perspective, as actually it is possible that proverbs heard in childhood manifest the gender related authority - the authority of women.

Thus, it may be that Finnish proverbs would not be the expressions meant to protect or uphold patriarchal society, as has been suggested. However, as a part of pedagogical speech the proverbs were mainly connected to women's talk: in childhood the majority of proverbs were heard from women. These women were the most important authorities in children's everyday lives mothers and grandmothers (Granbom-Herranen 2004, 2008). This is not at all unexpected when thinking about bringing up children. Anyhow, gender and its possible significance in using proverbs may turn out to have an influence either on possible hidden meanings in proverbs or on the use of proverbs as a women's tradition of denial (Granbom-Herranen 2004, 2009b). ${ }^{6}$

Example 1 (SKS.KRA.PE 682-1085.1985/1921/N)

Äiti myös tähdensi, että vaikka kuinka huonosti elämässä kävisi, niin koskaan ei saa lannistua, - hänen mielilauseensa olikin, että "Ihminen menee vaikka läpi harmaan kiven" jos on pakko.

My mother impressed on us that it may go badly in life, but you should not give up - her favourite phrase was "a man or a woman goes even through the grey stone" if you have to.

Example 2 (SKS.KRA.PE 8239-8298.1985/1923/N)

Hän [äiti] osasi esimerkiksi loputtoman määrän sananparsia ja sanomuksia. Joka tilanteeseen hänellä oli monta sananpartta. [---] Kun 
rahat eivät tahtoneet riittää, äiti valitteli: "Kaikkia siton kun on köyhiäkin" tai "Milläs täi rykii kun ei oo rintoja".

She [mother] knew for example an endless amount of proverbs and sayings. For every occasion she had many proverbs. [---] When the money was not stretching to a living, mother complained: "There is everything, even the poor ones" or "With what shall the louse clear its throat when it doesn't have any chest."

When narrating the proverbial speech the main thing is not the gender of the narrator. Women as the speaker cannot be determined by the gender of the listener: both girls and boys have heard proverbs in their childhood. They all did not use the proverbs later in their lives (Granbom-Herranen 2004: 43; 2008: 238).

In Finnish tradition, we have been accustomed to think that men have taught children to work, especially the boys. On the other hand, it has been said that within the Finnish speaking part of society fathers have been responsible for teaching the Christian doctrine, according to the patriarchal model (Granbom-Herranen 2009b: 86). Anyhow, in the matter of proverbial speech in one's childhood this does not seem to be confirmed. Mothers and grandmothers are mentioned to be the users of proverbs in every second case where the speaker is mentioned, fathers and grandfathers are mentioned only in every fifth case.

Table 1. The users of proverbs in childhood memories

$45 \%$ mother or grandmother

$20 \%$ father or grandfather

$15 \%$ not mentioned

$10 \%$ parents

$10 \%$ neighbours and village people

\section{Example 3 (SKS.KRA.PE 5356-5559.1985/1910/M)}

"Terävä tekevän veitsi, tylsä veihti tyhmän miehen", oli isäni suosiossa oleva sananlasku, jota hän usein meille lapsilleen teroitti. Niinpä mekin saimme omat leikkikalumme, lastuista vuoleksitut hevoset, lehmät ja lampaat, ynnä muut lelumme valmistaa itse neli-viisi vuotiaasta alkaen ja opetella teräaseen käsittelyä ennen kuin peukalo on kasvanut kämmenen keskelle. Ei isäni silti kovinkaan paljon näitä sananlaskuja harrastanut 
opetusmielessä, eikä muutenkaan, siksi niitä on vähän muistissani. Äitini niitä viljeli runsaasti, siitä myöhemmin.

"The knife of a hardworking man is sharp, a stupid man has a blunt knife" was the favourite proverb of my father and he often pointed this out to us. So we got to make our own toys like horses, cows, and sheep. We made them since we were four or five years old. We had to learn how to use a knife before the thumb grows into the middle of the palm. My father didn't use a lot of these proverbs when teaching us or in other situations. This is why I don't remember so many of them. My mother used them often, I'll tell about it later on.

\section{PROVERBS FROM CHILDHOOD HAVE MANY ASPECTS}

What makes proverbs in pedagogical speech so meaningful is the fact that they are the language of power and authority, the very first authority in children's lives. Proverbs are unchallenged speech that can be over-ridden only with another proverb (Granbom-Herranen 2004: 51; Goodwin \& Wentzel 1994: 153). From the pedagogical point of view, it is important that proverbs follow people all through their lives. As the proverb is owned by the user, it is mostly associated with some special person (Briggs 1988; Granbom-Herranen 2004; 2008). For children proverbs are not merely a tradition passed on by parents, grandparents and other grown-ups. The proverbs from childhood include words with literal meanings, but they also include much more and they are combinations of sociocultural context, people, emotions and information in different situations. The power of childhood proverbs does not lie in the metaphorical wisdom of the ancient times; it lies in the child's comprehensive experience. When the proverb is heard it is connected to the owner of the proverb and the situation in which it was heard for the first time. That is what the children remember and what they seem to go back to when using and/or meeting the proverb later in their lives.

\section{Example 4 (SKS.KRA.PE 13265-13290.1985/1919/N)}

Mummoni s. 1872, antoi meille poikansa lapsille elämänohjeet ja kasvatti meidät. Tärkein oli Jumalan pelko: "Hän näkee kaikki, ei Hänen tietämättään hiuskarvasi putoa." Raamatun lauseita ei puuttunut, mutta se teki elämän turvalliseksi, kun oli sanat jokaiseen tilanteeseen. Tietoa oli hyvin paljon vähemmän kuin nykyajan lapsella, oli helppo uskoa kaikki, mitä sanottiin. "Jokainen, joka vitsaa säästää, se vihaa lastaan, ja kuka kuritta kasvaa se kunniatta kuolee", sanottiin. Eivät ne vitsat ja 
tukkapöllyt ihan mukavalta tuntuneet, mutta hyvin pienenä oppi tajuamaan, että se oli minulle parhaaksi, vaikka ei kunnialla kuolemista ymmärtänytkään.

My grandmother (born in 1872) brought us up and gave us the guidelines of life. The most important was the fear of God: "He sees everything. Not a single sound falls out unbeknown to Him." There was no lack of Bible quotations. Anyhow, it made life safe, when you always had a word for every situation. We had much less knowledge and information than children nowadays have. It was easy to believe all that was said. We were told: "Everybody who spares the rod spoils his child, and the one who lives without any discipline, will die without any honour." Those beatings by rods and pulling of the hair were not pleasant, but already as a little child I learned that it was for the best; even if I didn't understand anything about "the dying without honour". ${ }^{7}$

As mentioned before, in the use of proverbs, it is not only the words that matter but also the feelings and emotions read into proverbs in each situation. The material of the life-stories indicates that for a child a proverb is first and foremost concrete advice. The time for thinking about the proverb, as well as looking for and finding symbolism in it does not come until adulthood. Anyhow, the interpretation made in childhood is the most important during adulthood (Granbom-Herranen 2008: 274).

The life-stories tell us that even in adulthood the proverbs used by mothers and grandmothers are considered to be those ones with importance. We can assume that the use of proverbs in everyday functions has been - and still is more like something that comes and goes rather than wisdom used after long consideration. This does not mean, however, that when the listener is a child the proverb would be understood in its assumed standard proverbial interpretation, the way it is done when an adult is the listener. ${ }^{8}$ For the adult proverbs have a different meaning than for the child, even though the proverbs recollected from childhood were connected with work, they were also interpreted through the emotions aroused by both the speaker and the situation itself.

If bringing up children by using proverbs was merely a matter of learning from the female model or behaviouristic learning, it would mean that only girls but not the boys began to use proverbs in their speech. As we know, it is not as simple as that. Actually, very few narrators mentioned using proverbs themselves when bringing up and training their own children or grandchildren. There were, however, some such cases. Everybody who mentioned that they use proverbs in their own speech had also heard someone use them in 
their childhood. Every user of proverbs had earlier been a listener, but not vice versa: not everybody who had heard proverbs mentioned using them, thus it does not become clear on what grounds the use of proverbs is transmitted to the next generations (children or grandchildren). The proverbs follow a person for all his/her life time.

\section{Example 5 (SKS.KRA.PE 13265-13290.1985/1919/N)}

The narrator has been a listener of the proverb in her childhood and she has used them when bringing up her children and grandchildren. Finally, she is a grandmother and a listener to the same proverbs used by her grandchild. The motivation for the proverbs lies in the past as the narrator was brought up by her own grandmother, who was born in 1872. The narrator had been told to take care of her clothes in her childhood. Still, at the beginning of the 20th century, clothes were expensive and quite difficult to get in Finland.

Siisteys oli myös tärkeää. Sanottiin, "vaate kaunis vanhanakin, jos on puhdas ja eheä' ... Vaatteita arvostetiin, sanottiin, 'kel ei o riihe rimpsutinta, sil ei uo kirko kimpsutinta'. Näin on tullut sanottua omille lapsille ja lapsenlapsille.

Ensimmäinen lapsenlapseni (15v) tuli luokseni viime keväänä, päällään rikkinäiset farmarit. Tietysti sanoin ensimmäiseksi, voi kauhia, Eikös hän taputtanut olalle ja sanoi, 'mummo, olet itse opettanut, 'kel ei uo riihe rimpsutinta ... ja ryysyissä se raha lepää ja kel o paikka paika pääll, sil o markka marka pääl'.

Ei siinä voinut olla vihainen ja kaikki tuli vielä hyvällä karjalan murteella.

Cleanliness was important. It was said "even an old cloth is beautiful, if it is clean and undamaged." ... The clothes were valued. It was said "One who does not have work clothes does not have anything to put on when going to church." I have told this also to my children and grandchildren.

My first grandchild (15 years) came up to me, dressed up in ragged and worn out jeans. Of course the first thing I said was "So horrible!" So she clapped me on the shoulder and said: "Grandmother, you have taught us that "one who does not have ..." and "in rags there is property" and "one who has a patch over a patch has a coin over a coin."

I could do nothing but laugh - when she, above all else, said it in a beautiful Karelian dialect. 


\section{Example 6 (SKS.KRA.PE 682-1085.1985/1926K/N)}

Huomaan usein toistavani äidin opetuksia esim. "Kerrall' laiska katkijaa, viijest viriä käyp" tai "vie männeissäs, tuo tulleissas, tie siel ollessais, mäkätä männeissäs" jne.

I notice that I often repeat the morals of my mother, e.g. "You need only one time to tire out a lazy person, for a sprightly one you need five times" or "When you come, bring the things, when you go, take the things, bring it with you when you come, do when you are there, and during the time you are going", etc.

\section{CONCLUSION}

Proverbs in childhood memories can be seen as a part of gender related folklore, especially in the early years. Proverbs are a tradition that is transmitted from two generations, from the parents and grandparents to the children and youth. It might also have been older sisters who take care of the younger ones. As a part of pedagogical speech the proverbs are connected to women's talk. These women are the most important authorities in children's everyday lives - mothers and grandmothers. The life-stories show that proverbs used by parents and grandparents are seen to be special even in one's adulthood. From the pedagogical point of view, it is important that the proverbs follow people all through their lives. Passing from one generation to another, proverbs have been the speech of the family and the neighbourhood.

As the proverb is owned by the user, it is mostly associated with some special person. Thus, when a proverb is heard it is connected to the owner of the proverb and the situation in which it was heard for the first time. Presumably just the feelings and emotions connected with the situation or some parts of it - like the speaker - are things to facilitate the use of the proverb in some special occasion later in life. Or vice versa, they can explain why some situations cannot occur without some special proverbs.

The personified users of proverbs in childhood are mothers and grandmothers. ${ }^{9}$ The grandmother as the speaker can perhaps be explained by the fact that during the time when parents were working outside the home, the grandmother had the main responsibility for the children. In the everyday life of children when raising and educating them, mothers and grandmothers have been those whose proverbs, advices, guidance, moral and wise words have got the place in the children's minds. When dealing with gendered culture and tradition there is always the possibility that phenomena, connected to subcul- 
tures, emerge. It is just as possible that tacit knowledge manifests itself as the culture of denial and it may be so that all the proverbial speech in Finnish during the Swedish or Russian time may have been the speech of denial, a part of speech used by ordinary people in class society. The phenomenon might have had connections with the sub-cultural communication as some parts of proverbs might also have been meant to be women's talk in the patriarchal society. It is conceivable that the tacit knowledge manifests itself inside the main culture.

Anyhow, if we look at the proverbs as tools of the power and authority in bringing up children, we come to the conclusion that in this narrative material it has primarily been women who have used this power. The situation is the same when we look at the number of the speakers in relation to the number of the proverbs and the number of the speakers regarding the number of the narrators. (Granbom-Herranen 2004: 65-66.) This is interesting because, in Finnish tradition, proverbs have been seen as the folklore genre used mostly by men and which underpins the patriarchal system. One of the reasons might have been that both the collectors of folklore material and the informants were still, at the beginning of the 20th century, men. They suited the everyday life of men, maybe not always that but mostly. On the other hand, the most self-evident part of women's everyday life has been taking care and bringing up children.

Olen yrittänyt opettaa näitä asioita myös omille lapsilleni ja lastenlapsilleni. Myös perhepäivähoitajana olen yrittänyt opettaa hoitolapsilleni toisen ihmisen arvostamista. Muistan aina äitini opetuksen, "arvaa oma tilasi, anna arvo toisellekkin".

I have tried to teach these things to my children and grandchildren. As well as a day-mother I have tried to teach the children to respect others. I do always remember the teaching of my mother, "be aware of your own situation, giving also value to the others". ${ }^{10}$

\section{ACKNOWLEDGEMENTS}

This article is a part of the author's project "Proverbs from Childhood - Intentions and Interpretations". The project has been financial supported by a grant of the Research Center of Mannerheim League for Child Welfare in Finland. 


\section{NOTES}

1 SKS.KRA.KE 8840-8907.1984/1917/M. I use the reference: SKS (Suomalaisen Kirjallisuuden Seura/The Finnish Literature Society), KRA (Kansanrunousarkisto/The Folklore Archive) and PE or KE (the names of the collections: Perinne elämässäni 'Tradition in my life' and Karjalaiset elämäkerrat 'Karelian biographies'). The page numbers refer to the pages in the collections. The first year refers to the time the material has been sent to the archive and the second one is the year of birth (if not known I use "xxx") N/W or M/M stands for the gender. The Finnish language of the examples is in the form the narrator has written it. All the translations are made literally by L. G.-H.

2 Kuusi 1971: 100; see also Nenola 1986: 100-101; Saarnivaara 1989: 91; Apo 1995: 56; Stark 2005: 67.

${ }^{3}$ I have focused on the Finnish speaking majority even though in Finland there were also ordinary people who spoke Swedish (about 5-10\%).

4 In Finland (actually Sweden) there were universities, the first was established in 1640 in Turku. However, the universities were not for the Finnish speaking part of the population. The aim of the Lutheran church was to make everybody literate and capable of reading the Bible (Church Code in 1686). Although both the Bible and the statutes existed in the written form also in the Finnish language already from the 17 th century, they were read for the people in the church, during the church service. Anyhow, illiteracy was common and the oral tradition powerful.

5 Ilhan Başgöz (1990: 7) has written about the folk definitions of proverb. See also Barakat 1980: 5, 7, 13, 41; Granbom-Herranen 2008: 35-38.

${ }^{6}$ More about the women's tradition of denial in folklore traditions, see Nenola 1990.

7 Origin in the Bible, the Book of Proverbs 13:24: He that spareth the rod, hateth his son: but he that loveth him, correcteth him betimes.

Finnish transl. in 1776: 'Joka vitsaansa säästää, hän vihaa lastansa; vaan joka häntä rakastaa, hän aikanansa sitä kurittaa.'

Finnish transl. in 1933/38: 'Joka vitsaa säästää, se vihaa lastaan; mutta joka häntä rakastaa, se häntä ajoissa kurittaa.'

${ }^{8}$ More about the standard proverbial interpretation (SPI) see, e.g., Norrick 1985: 1.

9 About the influence of grandmother's proverbs see, e.g., Alexander \& Hasan-Rokem 1988: 8; Newall 1994: 193.

10 SKS.KRA.PE 10271-10277.1985/1923/N. 


\section{MATERIAL}

The Folklore Archives of the Finnish Literature Society in Helsinki:

Karjalaiset elämäkerrat -keruu 1983-1984. [Karelian biographies]

Perinne elämässäni -kilpakirjoitus 1985. [Tradition in my life]

\section{REFERENCES}

Alexander, Tamar \& Hasan-Rokem, Galit 1988. Games of Identity in Proverb Usage: Proverbs of a Sephardic-Jewish Woman. Proverbium: Yearbook of International Proverb Scholarship, Vol. 5, pp. 1-12.

Apo, Satu 1995. Naisen väki. Tutkimuksia suomalaisten kansanomaisesta kulttuurista ja ajattelusta. Helsinki: Hanki ja Jää, pp. 50-74.

Barakat, Robert A. 1980. A Contextual Study of Arabic Proverbs. Folklore Fellows' Communications 226. Helsinki: Academia Scientiarum Fennica/Suomalainen Tiedeakatemia.

Başgöz, Ilhan 1990. Proverbs about proverbs or folk definitions of proverb. Proverbium: Yearbook of International Proverb Scholarship, Vol. 7, pp. 7-17.

Briggs, Charles L. 1988. Competence in Performance. The Creativity of Tradition in Mexicano Verbal Art. Philadelphia: University of Pennsylvania Press.

Devitt, Michael \& Sterelny, Kim 1987. Language and Reality: An introduction to the Philosophy of Language. Oxford: Basil Blackwell.

Dolby, Sandra K. 1989. Literary Folkloristics and the Personal Narrative. Bloomington, Indiana: Trickster Press.

Finnegan, Ruth 1994. Proverbs in Africa In: W. Mieder \& A. Dundes (eds.) The Wisdom of Many: Essays on the Proverb. Madison, Wisconsin: The University of Wisconsin Press, pp. 10-42.

Goodwin, Paul D. \& Wentzel, Joseph W. 1994. Proverbs and Practical Reasoning: A Study in Socio-Logic. In: W. Mieder \& A. Dundes (eds.) The Wisdom of Many: Essays on the Proverb. Madison, Wisconsin: The University of Wisconsin Press, pp. 140160.

Granbom-Herranen, Liisa 2004. Sananlaskujen käyttäjät ja käyttöyhteys. Sananlaskut käyttökontekstissaan 'Perinne elämässäni' -kilpakirjoituksen aineistossa. Pro gradu -tutkielma. Kulttuurien tutkimuksen laitos. Helsingin yliopisto. http:// urn.fi/URN:NBN:fi-fe20051452, last accessed on 20 Nov, 2010.

Granbom-Herranen, Liisa 2008. Sananlaskut kasvatuspuheessa-perinnettä, kasvatusta, indoktrinaatiota? Jyväskylä Studies in Education, Psychology and Social Research 329. Jyväskylä: Jyväskylän Yliopisto. http://julkaisut.jyu.fi?id=978-95139-3111-7 (includes a summary in English, pp. 278-285), last accessed on 20 Nov, 2010.

Granbom-Herranen, Liisa 2009a. Proverbs from childhood. Proverbium: Yearbook of International Proverb Scholarship, Vol. 26, pp. 151-170.

Granbom-Herranen, Liisa 2009b. Mihin sananlasku lasta johdattaa? Elämäntarinoiden avulla lapsen tulkintaan sananlaskujen kasvatustavoitteista. Kasvatus 
\& Aika, Vols. 3-4/2009, pp. 79-93. http://www.kasvatus-ja-aika.fi, last accessed on 20 Nov, 2010.

Katajala, Kimmo 2005. Suurvallan rajalla. Ihmisiä Ruotsin ajan Karjalassa. Historiallinen arkisto 118. Helsinki: Suomalaisen Kirjallisuuden Seura.

Korkiakangas, Pirjo 1996. Muistoista rakentuva lapsuus. Agraarinen perintö lapsuuden työnteon ja leikkien muistelussa. Kansatieteellinen arkisto 42. Helsinki: Suomen Muinaismuistoyhdistys.

Kuusi, Matti 1954. Sananlaskut ja puheenparret. Helsinki: Suomalaisen Kirjallisuuden Seura.

Kuusi, Matti 1971. Naisen arvo Suomen ja Ambomaan sananlaskustossa. Suomen Akatemia, Vol. 1, pp. 99-107. Also in Kuusi, Matti. (1985) Perisuomalaista ja kansainvälistä. Tietolipas 99. Helsinki: Suomalaisen Kirjallisuuden Seura, pp. $110-123$.

Kuusi, Matti 1983. Maailmankansojen yksi- ja erimielisyys. In: M. Kuusi \& O. Lauhakangas (eds.) Maailman sananlaskuviisaus. Porvoo: Werner Söderström Osakeyhtiö, pp. 9-21.

Nenola, Aili 1986. Miessydäminen nainen. Naisnäkökulmia kulttuuriin. Tietolipas 102. Helsinki: Suomalaisen Kirjallisuuden Seura, pp. 91-115.

Nenola, Aili 1990. Sukupuoli, kulttuuri ja perinne. In: A. Nenola \& S. Timonen (eds.) Louhen sanat. Kirjoituksia kansanperinteen naisista. Suomalaisen Kirjallisuuden Seuran toimituksia 520. Helsinki: Suomalaisen Kirjallisuuden Seura, pp. 1123.

Newall, Venetia J. 1994. A tradition bearer: memories of my grandmother. Proverbium: Yearbook of International Proverb Scholarship, Vol. 11, pp. 189-196.

Norrick, Neal R. 1985. How Proverbs Mean: Semantic Studies in English Proverbs. Trends in linguistics. Studies and monographs 27. Berlin: Mouton.

Pentikäinen, Juha 1980. Yksilö perinteentutkimuksen kohteena. In: O. Lehtipuro (ed.) Perinteentutkimuksen perusteita. Porvoo \& Helsinki \& Juva: Werner Söderström Osakeyhtiö, pp. 185-248.

Ricoeur, Paul 1980. The Metaphorical Process as Cognition, Imagination, and Feeling. In: S. Sacks (ed.) On Metaphor. Chicago, Illinois: The University of Chicago Press, pp. 141-157.

Saarnivaara, Marjatta 1989. Nainen ja mies - eilen, tänään, huomenna. In: A. Haataja \& E. Lahelma \& M. Saarnivaara (eds.) Se pieni ero. Kirja tasa-arvokasvatuksesta. Helsinki: Valtion painatuskeskus, pp. 83-120.

Siikala, Anna-Leena 1984. Tarina ja tulkinta. Tutkimus kansankertojista. Suomalaisen Kirjallisuuden Seuran toimituksia 404. Helsinki: Suomalaisen Kirjallisuuden Seura.

Stark, Eija 2005. Oma apu paras apu. Katsaus maalaisköyhälistön moraalitalouteen. In: P. Laaksonen \& S. Knuuttila \& U. Piela (eds.) Kansanetiikkaa. Käsityksiä hyvästä ja pahasta. Kalevalaseuran vuosikirja 84. Helsinki: Suomalaisen Kirjallisuuden Seura, pp. 65-83.

Stark, Laura 2008. Maalaisrahvaan kirjoitusmotivaatio ja asenteet kirjoitustaitoa kohtaan 1840-1890-luvun Suomessa. Kasvatus \& Aika, Vol. 3/2008, pp. 49-66. www.kasvatus-ja-aika.fi/site/?lan=1\&page_id=140, last accessed on 20 Nov, 2010 . 
Taylor, Archer 1994. The Wisdom of Many and the Wit of One. In: W. Mieder \& A. Dundes (eds.) The Wisdom of Many: Essays on the Proverb. Madison, Wisconsin: The University of Wisconsin Press, pp. 3-9.

Titon, Jeff Todd 1980. The Life Story. Journal of American Folklore, Vol. 93, pp. 276-292.

Ukkonen, Taina 2000. Menneisyyden tulkinta kertomalla. Muistelupuhe oman historian ja kokemuskertomusten tuottamisprosessina. Suomalaisen Kirjallisuuden Seuran toimituksia 797. Helsinki: Suomalaisen Kirjallisuuden Seura. 